\title{
底面水抜きスクリーン実験に対する 水と礫の分離挙動シミュレーション
}

\author{
堀口 俊行 1 - 香月 智 2 \\ 1 学生会員 防衛大学校理工学研究科後期課程（干239-8686 神奈川県横須賀市走水 1-10-20) \\ E-mail:ed12007@nda.ac.jp \\ 2正会員 防衛大学校教授 システム工学群建設環境工学科（テ239-8686 神奈川県横須賀市走水1-10-20) \\ E-mail:katsuki@nda.ac.jp
}

\begin{abstract}
本研究は，土石流中の水と礫を分離させることによって，捕捉された巨碟を停止させる底面水抜きスク リーンの実験を行い，個別要素法を用いたシミュレーションで再現解析したものである. 実験では, 堰堤 に堆積した磎の停止位置と形状および流下方向に区分された領域ごとに土石流から分離落下した水量につ いて計測した. 次に, 礫と水の連成挙動を個別要素法によって解くための擬水滴要素を提案し, 実験の再 現解析を行った。解析では, 碩の堆積過程と区分ごとの水量をシミュレーションし, 各要素間の接触力分 布や速度べクトルを時刻歴で分析することにより，土石流の停止機構について検討した。
\end{abstract}

Key Words: DEM, debris flow, spherical water model, bottom drainage screen

\section{1. 緒 言}

近年，気候変化に伴い局地的なゲリラ豪雨や大型台風 による集中豪雨が発生し，土石流や地すべり等が頻発し ている.このため最近の自然災害における豪雨災害の影 響は増加傾向にある ${ }^{1)}$ 2). 土石流対策の一つに，砂防堰 堤が建設されており人命や財産を守っている. 砂防堰堤 は，不透過型と透過型の二種類に分けられる ${ }^{3)}$. 不透過 型は，土石流時だけでなく平常時の流出土砂も貯留する ものであり，古くから建設されてきた。しかし，堆積し た土砂の処理や生態系の分断および下流側の河床低下 の影響などの環境に配慮して, 建設数は減少傾向にある. 一方, 透過型は平常時の土砂や流水はそのまま流し, 土 石流時には先頭部に集中する巨砂を捕捉することで，堰 堤の透過部が閉塞され後続流である土砂を捕捉する ${ }^{4}$. このため, 最近では透過型砂防堰堤が多く建設される傾 向にある 5). その中で，写真-1 のような底面水抜きスク リーンと呼ばれる堰堤も建設されている 9 。底面水抜き スクリーンは，スノコ状のデッキを渓流河床に作り，土 石流を堰堤上で砅と水に分離させ，土石流を減速，停止 そして堆積させるものである ${ }^{7,8)}$.

研究上の背景として, 橋本 ${ }^{9}$ は分離方式による砂防工 法の一環として本構造が土石と水を分離させることで停 止させる作用を簡単な模型実験で再現した．そのうえで， 実物大実験として分離堰堤を用いて, 実用化に向けて礫

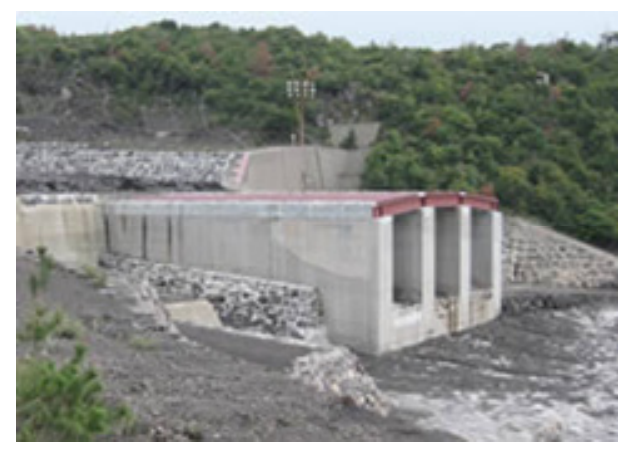

写真-1 底面水抜きスクリーン

と水の分離機構を整理した．また，矢沢ら ${ }^{10}$ は模型実験 に基づき石碩型と泥流型土石流をモデル化し，それぞれ の土石流に対して底面水抜きスクリーンによる捕捉状況 を考察した. そして，堆積塊に対するスクリーン長やス リット間隔，堰堤の傾斜角度の影響を検討した。 そのう えで，捕捉された堆積物に対しても考察しており，土石 塊の堆積過程やその安息角の形状，停止距離についても 整理し，設計の参考にされている.

権田ら ${ }^{11-14)}$ は，土石流中の液相と固相における内圧の 変化や礫と水の分離について力学モデルを構築し，実験 結果と比較・検討した，そこでは，液相の圧力の減少に ともなうせん断抵抗力の増加が，スクリーン上における 土石流の停止機構に対する支配的要因としている.

一方, 数值解析法に基づいて土石流を解析する研究も 


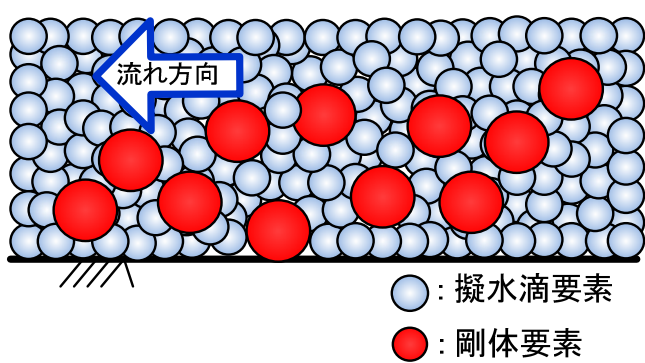

図-1 擬水滴要素を用いた土石流モデル

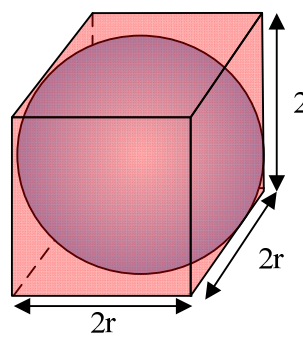

図-2 等価体積

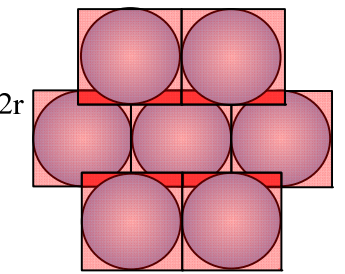

(a) 最密充填

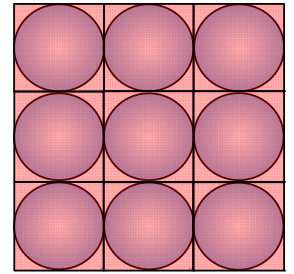

(b) 規則配列

図-3 配列と等価領域の重なり

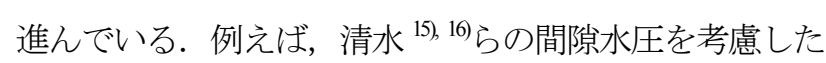
粒子一流体連成モデルの研究では，固体粒子より小さい スケールで粒子周りの流れ場を解析し，流体力を算出す ることで，固体粒子の移動を解析している．また，流体 および石砶モデルをともにラグランジュ解析する粒子法 によって, 石礫周りを流れる流体力の評価が検討されて いる ${ }^{17)}$. 例えば，加藤ら ${ }^{18)}$ は連続体の基礎式のラグラン ジュ的な離散化を可能にした粒子法により, 減勢工モデ ルである固体粒子周りの流れを再現し，さまざまな流体 モデルによりその適用性を検討している. 浅井ら ${ }^{19}$ は, 設計時の流体力評価の援用として，数值流体シミュレー ションの比較をするため, オイラー型記述によるメッシ ユ型解析法やラグランジュ型記述による粒子型解析法の 特徵を整理し，それぞれの適用性およびその精度を検証 した. これらの手法は基礎となる流体解析の条件式を忠 実に解釈し, 数学的な整合性をもって構成されているの で緻密さにおいて長じている.

また，土石流に関する数值解析の一つとして個別要素 法を用いた研究がある 20), 21). 個別要素法を用いる場合は, 土石流の碩を剛体要素として与え, 礫に対する流体力に ついては，実験やモデル化された流速を基に，砶の動き とは無関係に抗力として与えることが多い. 例えば，淽 谷ら 22), 23) は円柱形要素を用いて流木混じり土石流モデル を開発し，実験との再現解析を行っている。また，捕捉 後の堆積した流木塊や流木混じり土石流の捕捉率の再現 性は高いものとなっている. しかし，碟の挙動に連成し ない流速分布を基に流体力を評価していることから，流 下過程において実験との再現性は高いが，堆積後の碩塊 に対して, 礫間を流れる水の動きは再現できていない. また，別府 24)らは，礫と水の連成解析のために個別要素 法と粒子法を連成解析している. そこでは，水を粒子法 により連続的に解き, 碟を個別要素法で解析するモデル を提案した. しかし，不連続体を前提として岡体の運動 を解く個別要素法と，連続体を前提とする粒子法を連成 させるため, 固体と流体の連続性の取扱いについて検討 の余地が残されている.

本研究は, 個別要素法でのモデル化の誤差を受容した うえで，水の動きを表現するための擬水滴要素を用いた 個別要素法を提案し, 礫と水の連成解析を行えるように
工夫した，そして，提案手法を用いて底面水抜きスクリ 一ン実験を解析し，水と硯の分離による土石流の停止機 構についてその再現性を検討したものである.

\section{2. 擬水滴要素}

\section{(1) 混相流のモデル化}

土石流は，固体の礫または土砂と水との混合流である が，従来の個別要素法による解析は，この固体部分のみ をP.A Cundall ${ }^{25}$ の提案した剛体要素にモデル化して解い ている ${ }^{26,27)}$. 本研究では，水の領域も図-1のような水滴 を模した球形の擬水滴要素の集まりとする，以下に，個 別要素法に組み込むための擬水滴要素の解法について述 ベる.

\section{（2）質量と体積}

擬水滴要素 $i$ の体積および質量は，球形を仮定してい るので次式によって与える.

$$
\begin{gathered}
V_{w i}=\frac{4}{3} \pi r_{w i}^{3} \\
m_{w i}=\frac{4}{3} \rho_{w e i} \pi r_{w i}^{3}
\end{gathered}
$$

ここで, $V_{w i}$ : 擬水滴要素 $i$ の体積, $r_{w i}$ : 擬水滴要素 $i$ の 半径, $m_{w i}$ : 擬水滴要素 $i$ の質量, $\rho_{w i}$ : 擬水滴要素 $i$ の比 重である.

ただし，水の密度 $\rho_{w}$ については球形要素の表現すべき 領域を図-2に示すような立方体と考え，その質量を同じ になるように与えている. すなわち,

$$
\rho_{w e i}=\frac{8 r_{w i}^{3}}{4 / 3 \pi r_{w i}^{3}} \rho_{w}=\frac{6}{\pi} \rho_{w}
$$

ここで， $\rho_{w}$ : 水の密度 $\left(10^{3} \mathrm{~kg} / \mathrm{m}^{3}\right)$.

なお，後述する等価領域の重なりが全領域の質量表現 において現実の水の質量と矛盾することが予めわかって いる場合には，整合するように決定する.

また，流体解析における質量保存則については，個々 の要素の質量が無変化であることによって成立している ことになる. しかし, 個々の要素は等価体積としている ため, 体積の収縮と圧力の増大の関係については厳密に 


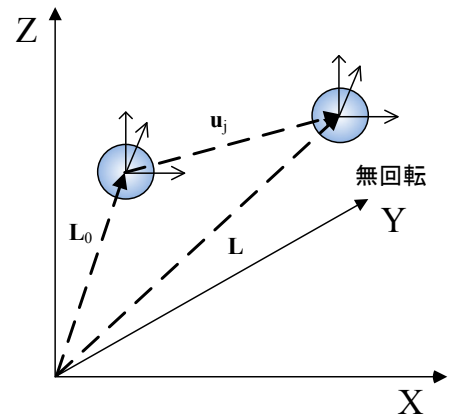

図-4 要素の位置と変位

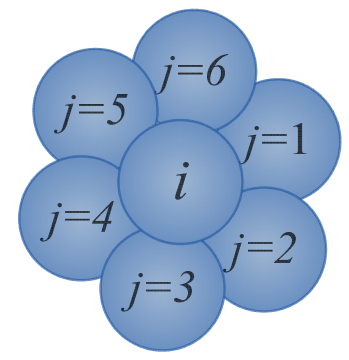

図-5 接触している周辺要素

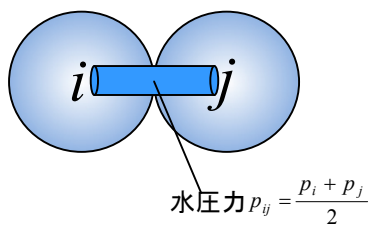

(a) 軽い接触時

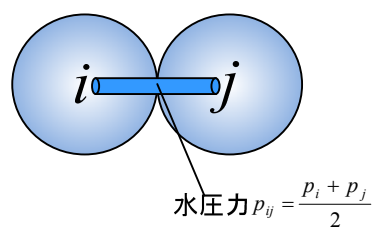

(b) 強い接触時

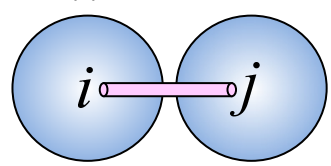

(c) 引張状態

図-6 圧力勾配力 $\mathbf{f}_{p i j}$ のモデル

成立することはできない，以下に，この点を詳述する．

図-3には，2次元における2種類の配列を示している. なお，図-3(a)は最密充填，図-3(b)は規則配列と呼ばれる ものである. 規則配列は，最密充填に比して間隙部分が 大きくなっている.これらに，図-2で示した等価領域を 描くと, 明らかに最密充填の方が，多くの重複領域が生 じている. 後述する処理法ではこの二つの配列において, いずれも球形要素の重なりがないと仮定して解析を行う が，このように等価領域の体積には相違が生じる.

個別要素法解析では, 個々の要素は時々刻々に移動し, 相互の位置関係は多様に変化するので, 図-3(a), (b)でも ない中間的な重なり状態を形成することになるが球形部 分の重なり以外は体積変化として評価することができな い.この点において「擬」モデルと呼ばざるをえない． ただし，㗂を球形とし，剛体とするなどのモデル誤差を 考慮すると, 連成モデルとしては適用問題によって妥当 であることも考えられる。

\section{(3) 運動量保存則}

流体解析においてNavier-Stokesの式は，次のように表 される28).

$$
\frac{D \mathbf{w}}{D t}=\mathbf{F}-\frac{1}{\rho} \operatorname{grad} \mathbf{p}+v \Delta^{2} \mathbf{w}
$$

ここで, $\mathbf{w}$ : 流水の速度ベクトルを表し, 右辺の第1項 は外力, 第2項は圧力, 第3項は粘性力を表している.

仮に, 擬水滴要素の個別要素内において密度が一定 であるとして，個々の要素 $i$ において運動量保存則を 要素の運動方程式として表わすと次式となる.

$$
\mathbf{M}_{w i} \ddot{\mathbf{u}}_{w i}(t)+\sum \mathbf{f}_{\mathrm{D} i j}\left(\dot{\mathbf{u}}_{w i}(t)\right)+\sum_{j} \mathbf{f}_{\mathrm{K} i j}\left(\mathbf{u}_{w i}(t)\right)=\mathbf{f}_{e x}(t)
$$

ここで, $\mathbf{M}_{w i}$ : 質量マトリクス, $\mathbf{f}_{e x}$ : 外力ベクトル, $\mathbf{f}_{\mathrm{D} j}$ : 要素 $i$ と隣接する要素 $j$ に働く人工減衰力ベクトル, $\mathbf{f}_{\mathrm{K} j}$ : 要素 $i$ と隣接する要素 $j$ に働く圧力勾配による力心゙ クトル, $\mathbf{u}_{w i}$ : 擬水滴要素 $i$ の変位ベクトル, ()$^{\circ},\left({ }^{\prime}\right)$ : 時 間に関する $1 ， 2$ 次微分を表す. また，式(5)の前提とし て, 要素内の変位, 速度, 加速度は一定であるとの仮 定を用いている.

また， $\mathbf{M}_{w i}$ は図-4に示すように並進方向成分だけを 扱うので㳄式となる. つまり, 要素の回転自由度によ って生じる角運動量は生じない.

$$
\mathbf{M}_{w i}=\left[\begin{array}{ccc}
m_{w i} & & \mathbf{0} \\
& m_{w i} & \\
\mathbf{0} & & m_{w i}
\end{array}\right]_{3 \times 3}
$$

なお外力ベクトルは, 後述する重力, 粘性力および 抗力ベクトルによって構成されている.

次に，図-4に示寸要素の位置と変位は，次のように 表す.

$$
\mathbf{L}_{w i}=\mathbf{L}_{w i}^{0}+\mathbf{u}_{w i}
$$

ここで， $\mathbf{L}_{w i}$ : 擬水滴要素 $i$ の重心の全体座標系に対寸 る位置ベクトル, $\mathbf{L}_{w i}{ }^{0}$ : 擬水滴要素 $i$ の初期の位置ベク トルである.

また，運動方程式の解法は，厳密性に劣るが計算効 率の良い中心差分法を用いた．ただし，速度に対して は，後進差分法を用いた。

$$
\begin{gathered}
\ddot{\mathbf{u}}_{w i}(t)=\frac{\mathbf{u}_{w i}(t+\Delta t)-2 \mathbf{u}_{w i}(t)+\mathbf{u}_{w i}(t-\Delta t)}{\Delta t^{2}} \\
\dot{\mathbf{u}}_{w i}(t)=\frac{\mathbf{u}_{w i}(t)-\mathbf{u}_{w i}(t-\Delta t)}{\Delta t}
\end{gathered}
$$

以上より，式(8)，(9)式を式(5)に代入して，時間 $(t+\Delta t)$ における変位 $\mathbf{u}_{n i}(t+\Delta t)$ は, 次式により求まる.

$$
\begin{aligned}
\mathbf{u}_{w i}(t+\Delta t)=\mathbf{M}_{w i}^{-1}\left\{\mathbf{f}_{e x}(t)-\right. & \left.\sum \mathbf{f}_{\mathrm{D} i j}\left(\dot{\mathbf{u}}_{w i}(t)\right)-\sum \mathbf{f}_{\mathrm{K} i j}\left(\mathbf{u}_{w i}(t)\right)\right\} \Delta t^{2} \\
& +2 \mathbf{u}_{w i}(t)-\mathbf{u}_{w i}(t-\Delta t) \quad(10)
\end{aligned}
$$

なお，式(10)は剛体要素の運動方程式 ${ }^{20,27)}$ と同じ形と なり, 擬水滴要素も従来の個別要素法と同じ解法で取 扱える.

\section{（4）圧力勾配によるカ}

水中にある擬水滴要素 $i$ は, 図-5に示すようにいくつ かの要素 $j$ によって囲まれている.この要素間に提案 する個別要素法では，図-6に示すように法線方向ばね の接触力に相当する水圧勾配力ベクトル $\mathbf{f}_{p j}$ を設ける. 


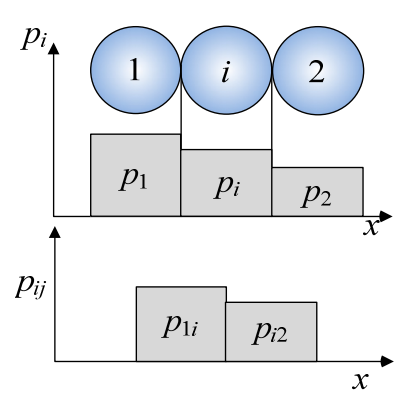

図-7 圧力勾配モデル

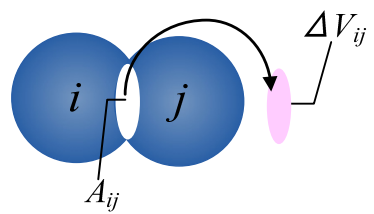

(a) 擬水滴要素の 2 体問題

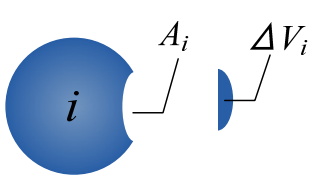

（b）接触面積

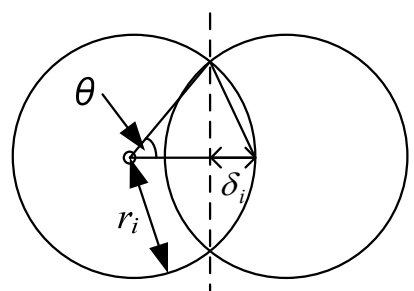

図-8 擬水滴要素の接触処理

図-9 擬水滴要素の接触面積の算出

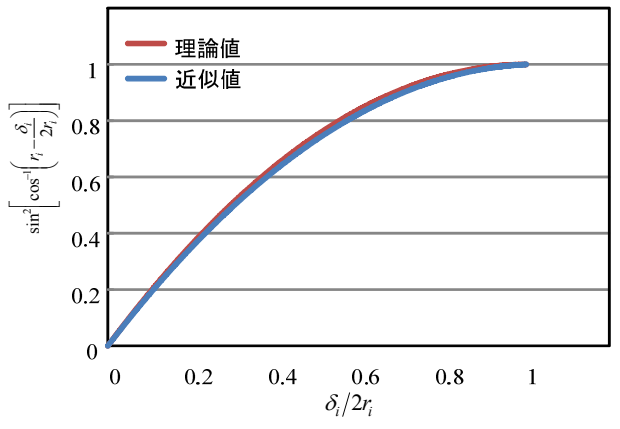

図-10 理論值と近似値

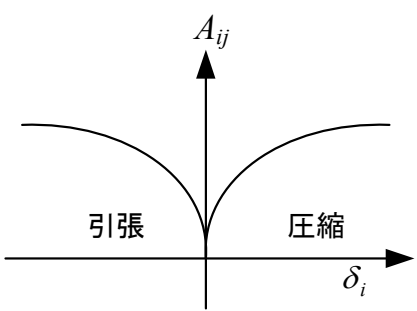

（a）接触面積〜重なり量

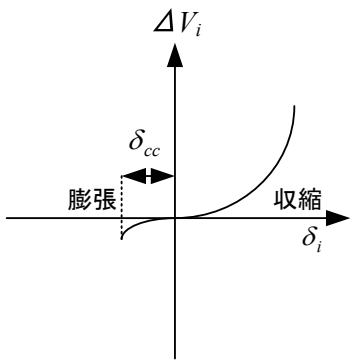

(b) 接触体積〜重なり量

図-11 内圧のための接触点処理モデル

この圧力勾配力については, 圧力と接触面積を乗じて 求めるものとする.

$$
\mathbf{f}_{p i j}=A_{c i j} \mathbf{p}_{i j}
$$

ここで， $\mathbf{f}_{p i j}$ : 要素 $i, j$ 間の圧力勾配による水圧力ベクト ル, $\mathbf{p}_{i j}$ : 要素 $i, j$ 間の圧力ベクトル, $A_{c i j}$ : 要素 $i, j$ 間の 接触面積である.

なお， $A_{c i j}$ は後述する式(18)を基に次式によって与える.

$$
A_{c i j}=\frac{A_{c i}+A_{c j}}{2}
$$

また， $p_{i j}$ は要素 $i$ と $j$ の内圧 $p_{i}, p_{j}$ の平均値を用いる.

$$
p_{i j}=\frac{p_{i}+p_{j}}{2}
$$

よって，図-7に示すような連続する擬水滴要素におい て，各擬水滴内の圧力は平均化されているが，隣接する 要素間に圧力差があるので, 要素 $i$ の左右の要素との圧 力勾配により，並進方向に動か寸力が生ずる.

\section{(5) 内 圧}

擬水滴要素 $i$ の内圧は，図-8に示寸ように隣接する要 素間の重複体積 $\Delta V_{i j}$ を用いて次式によって求める.

$$
\begin{gathered}
p_{i}=E_{w i} \frac{\Delta V_{i}}{V_{i}} \\
\Delta V_{i}=\sum_{j=1}^{n_{j}} \Delta V_{i j}
\end{gathered}
$$

ここで, $n_{j}: i$ 要素に隣接する要素数（配位数）.
なお， $E_{w i}$ は体積収縮に伴う圧力係数であり，基本値 として音速伝播速度を用いて与える29).

$$
E_{w i}=\rho_{w} C_{w}^{2}
$$

ここで, $C_{w}:$ 水の音速伝播速度.

$\Delta V_{j i}$ につては, 図-9に示寸ように接触に伴う重複半 径 $\delta_{\ddot{j}}$ を用いて次のように求める.

まず，接触面積 $A_{c i j}$ を厳密に求めると次式になる.

$$
A_{c i j}=\pi r_{i}^{2} \times \sin ^{2}\left[\cos ^{-1}\left(r_{i}-\frac{\delta_{i}}{2 r_{i}}\right)\right]
$$

これを多項式で近似して次のようにした。

$$
A_{c i j}=\pi r_{i}^{2}\left(-0.935\left(\frac{\delta_{i}}{r_{i}}\right)^{2}+1.935\left(\frac{\delta_{i}}{r_{i}}\right)\right)
$$

参考までに，式(17)と式(18)の近似式の比較を図-10に 示寸.

なお， $\delta_{i}$ は次式によって与えられる.

$$
\delta_{i}=\frac{r_{i}+r_{j}-l_{i j}}{2}
$$

ここで, $l_{i j}: 2$ 要素の中心点間距離である.

よって， $\Delta V_{i j}$ は式(18)を積分して次式で与える.

$$
\Delta V_{i j}=\pi r_{i}^{3}\left(-0.312\left(\frac{\delta_{i}}{r_{i}}\right)^{3}+0.968\left(\frac{\delta_{i}}{r_{i}}\right)^{2}\right)
$$

なお，体積膨張にも対応寸るため，式(18)については， 絶対值処理をするものとする，そのうえで，式(20)につ いて引張力に対応するため負值領域にも適用寸る. よっ 


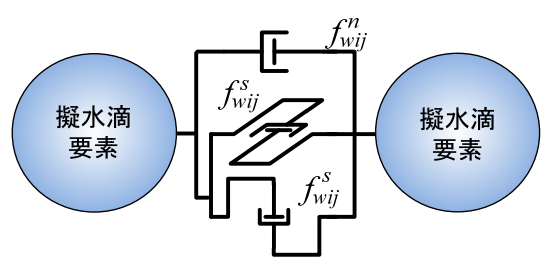

図-12 人工減衰モデル

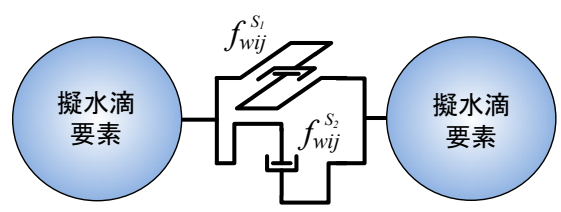

図-13 粘性モデル

剛体要素

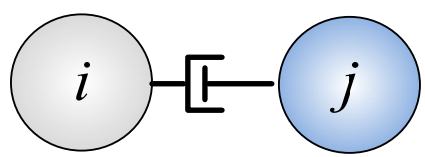

擬水滴要素

(a) 剛体要素と擬水滴要素

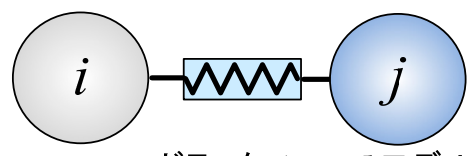

ドラックフォースモデル

(b) 抗力モデル

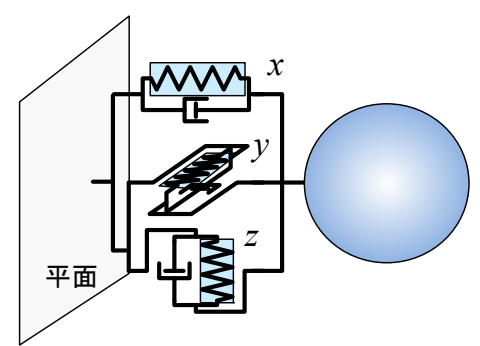

(c) 平面と擬水滴要素

図-14 擬水滴要素との連成

て，接触面積および重複体積の関数モデルは，図-11の ようになる，なお，重複体積の膨張側を距界離反距離 $\delta_{c c}$ でカットオフするのは, 自由水面からの離反をコントロ 一ルするためである.

\section{(6) 減衰と粘性力}

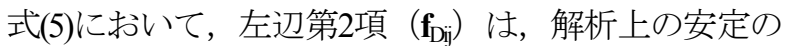
ために人工減衰として与える。つまり，図-12のように 法線方向と接線方向のダッシュポットとなるが，2つ係 数は, レイリー減衰モデル ${ }^{30}$ によって与える. 一方, 流 水の粘性については，図-13で示すモデルによって式(5) の右辺の一節として扱い, ニュートン流体モデルを基礎 として次式で与える.

$$
\begin{aligned}
& \tilde{f}_{w i j}^{s_{1}}=\eta_{w} A_{C i j}\left(v_{i}^{s_{1}}-v_{j}^{s_{1}}\right) \\
& \tilde{f}_{w i j}^{s_{2}}=\eta_{w} A_{C i j}\left(v_{i}^{s_{2}}-v_{j}^{s_{2}}\right)
\end{aligned}
$$
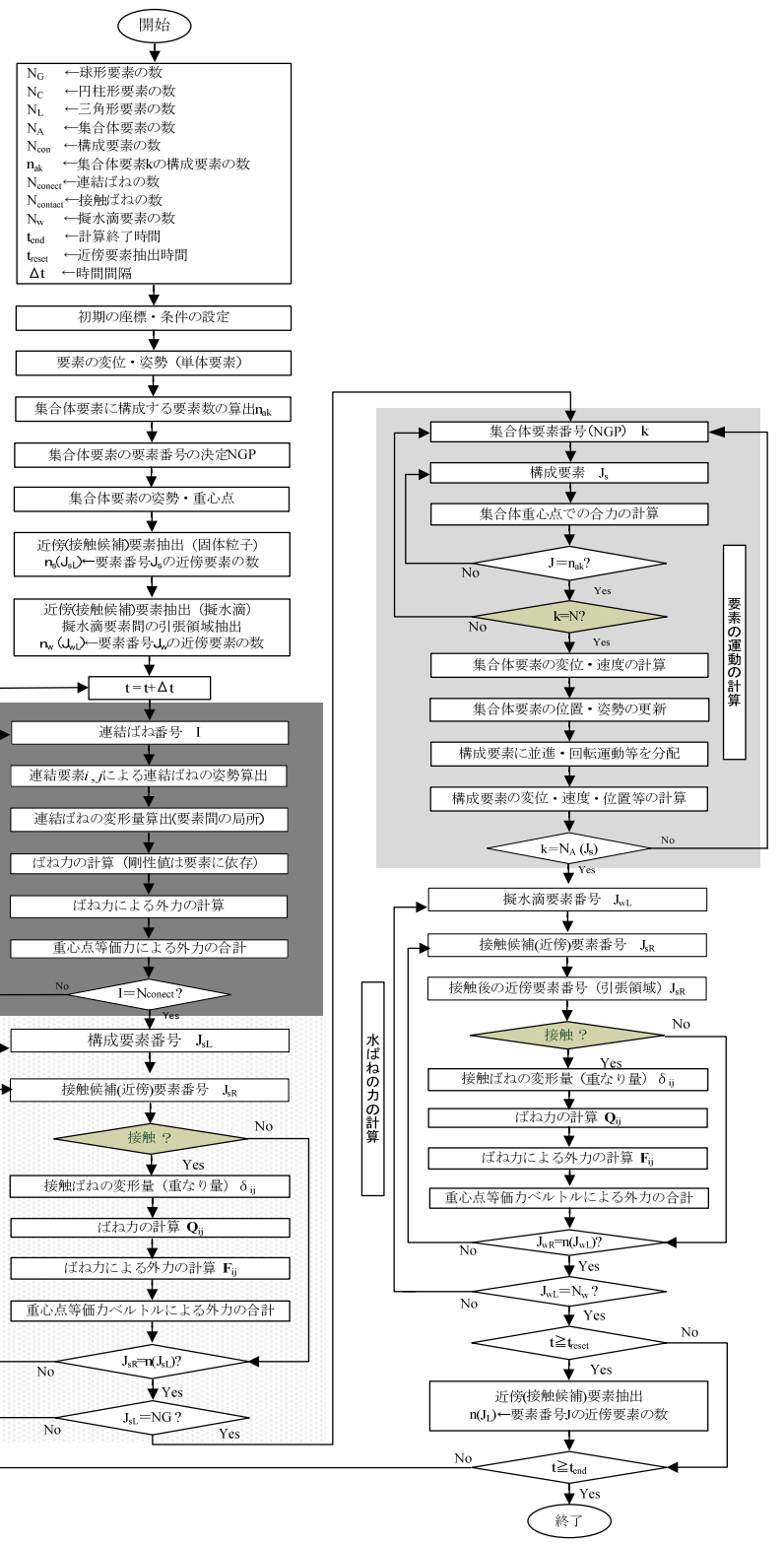

図-15 フローチャート

ここで, $\eta_{w}$ : 擬水滴要素間の減衰係数, $v_{i}, v_{j}: i, j$ 要素 の流速, $s_{l}, s_{2}:$ 直交寸る接線方向.

\section{(7) 擬水滴要素以外との連成}

擬水滴要素々球体もしくは円柱形の剛体要素間には, 図-14(a)に示すような人工減衰モデルと図-14(b)に示すよ うな抗力モデルを設ける. この抗力モデルに生じる局所 座標系における $\tilde{f}_{\text {Drag }}$ は, 次式によって与える.

$$
\tilde{f}_{\text {Drag }}=\frac{1}{2} C_{D} \rho_{w} A_{C i j}\left|\widetilde{v}_{i}^{n}-\widetilde{v}_{j}^{n}\right|^{2}
$$

ここで, $C_{D}$ : 抗力係数, $\widetilde{v}_{i}^{n}, \widetilde{v}_{j}^{n}$ : 局所座標系における 要素 $i, j$ の速度.

よって, 擬水滴要素は流速差が小さいと抗力を失い, 剛体要素をすり抜けられる.

一方, 図-14(c)に示寸平面要素との間には, 擬水滴要 


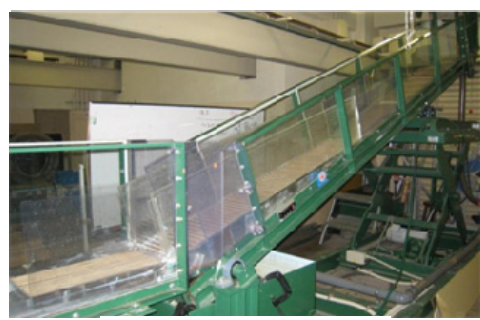

写真-2 実験水路

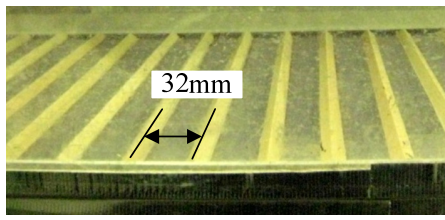

写真-3 三角形栈粗度

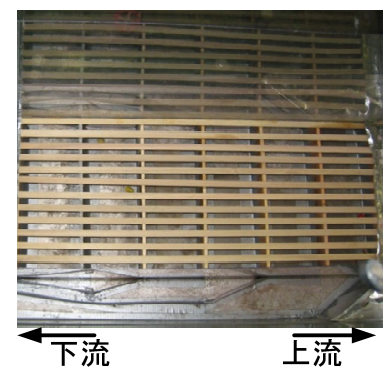

(a) 堰堤上面図

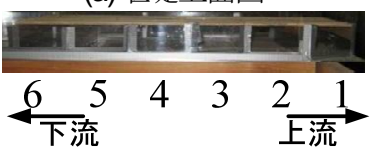

(b) 水槽番号

写真-4 底面水抜きスクリーン

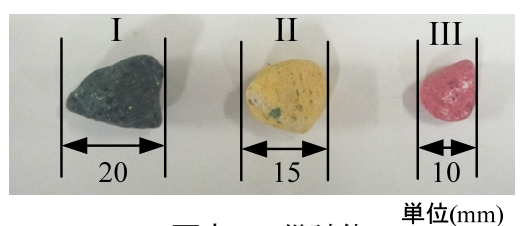

写真-5 供試体

表-1 供試体の諸元

\begin{tabular}{c|c|c|c|c}
\hline 区分 & 粒径 $(\mathrm{mm})$ & 比重 & 色 & 体積 $(\ell)$ \\
\hline I & $25 \sim 20$ & & 緑 & 1.0 \\
\cline { 1 - 2 } II & $20 \sim 15$ & \multirow{2}{*}{1.2} & 黄 & 1.5 \\
\cline { 1 - 2 } III & $15 \sim 10$ & & 赤 & 1.5 \\
\hline
\end{tabular}

素間に設けた減衰モデルを用いた，圧力勾配によるもの と人工減衰と粘性力を働かせる。 この際, 圧力勾配に相 当する水圧については，擬水滴要素の内圧とする.

$$
p_{i j}=p_{i}
$$

ここで, $i:$ 擬水滴要素番号, $j:$ 平面要素番号.

\section{(8) 座標変換と外カベクトル}

以上の接触点における抗力モデルに生じる力 $\tilde{\mathbf{f}}$ とする と，座標変換マトリクス $\mathbf{T}^{\mathrm{T}}$ 用いて全体座標系 $(x, y$, z）における力 $\mathbf{f}$ と変換される.

$$
\mathbf{f}=\mathbf{T}^{\mathrm{T}} \tilde{\mathbf{f}}
$$

また，外力ベクトル $\mathbf{f}_{e x}$ は，次式で与える.

$$
\mathbf{f}_{e x}=\left[\begin{array}{c}
f_{e x-x} \\
f_{e x-y} \\
f_{e x-z}
\end{array}\right]=\left[\begin{array}{c}
0 \\
0 \\
-m_{i} g
\end{array}\right]+\left[\begin{array}{c}
0 \\
0 \\
(\rho-1) V_{i j} g
\end{array}\right]+\left[\begin{array}{l}
f_{s-x} \\
f_{s-y} \\
f_{s-z}
\end{array}\right]+\left[\begin{array}{c}
f_{\text {Drag }-x} \\
f_{\text {Drag }-y} \\
f_{\text {Drag }-z}
\end{array}\right]
$$

ここで, 添字の $x, y, z$ は一般座標の方向を表し，第 1 項は自重, 第 2 項は浮力であり剛体要素のみに適用され る. 第 3 項，第 4 項はそれぞれ粘性力および抗力ベクト ルである.

\section{(9) 解析手順}

以上の基本式に基づく計算手順は，図-15に示すよう にばね力の計算, 剛体要素の運動, 擬水滴要素の運動の 処理に区分されて行われる.

\section{3. 底面水抜きスクリーン実験}

\section{(1) 実験装置の概要}

\section{a) 実験水路}

実験に用いた水路の概要を写真-2に示寸．装置は，勾 配が可変 $\left(0 \sim 20^{\circ}\right)$ の流下水路, 扇状地水路, 貯水槽, ゲートおよびラインポンプから構成されている. 流下水

\begin{tabular}{c|c|c|c}
\multicolumn{5}{c}{ 表-2 } & 実験ケース \\
\hline 実験条件 & 勾配 $\left({ }^{\circ}\right)$ & 流水量 $(\ell)$ & 備考 \\
\hline 流水のみ & 15 & 8 & 各5回 \\
礫混じり & 17 & 9 & ずつ実施 \\
& & 10 & \\
\hline
\end{tabular}

路の寸法は，長さ $4.35 \mathrm{~m}$ ，幅 $0.3 \mathrm{~m}$ ，深さ $0.5 \mathrm{~m}$ であり，底 面はステンレス，側面はガラスで内部観察できるように なっている. この水路の扇状地水路部分に，水抜き構造 部のため水路幅を $25 \mathrm{~cm}$ に狭めて設置した.

なお，流下水路底面には，写真-3に示寸ような三角形 粗度 ${ }^{31)}$ (栈高さ $4 \mathrm{~mm}$ ，栈間隔 $32 \mathrm{~mm}$ ）を配している.

\section{b) 底面水抜きスクリーン模型}

写真-4に，底面水抜きスクリーン模型を示す，幅 10 $\mathrm{mm}$ ，長さ $600 \mathrm{~mm}$ の木材を $10 \mathrm{~mm}$ の間隙を空けて並心゙ ている.なお，木材にあたる部分をスクリーン，間隙を スリットと呼んでいる. スリットから流れ落ちる水は, 写真-4(b)に示す区分 1 を上流側とし, 区分 6 を下流側と する 6 つの水槽に流れ落ちる. その後, 分岐した経路を 通って対応する水槽に水が貯まる機構となっている. よ って，各区間の落下する水量を計測することができる.

\section{c) 供試体}

礫材は，写真-5および表-1 に示す 3 種類の擬石を混合 したものである. なお，この材料は文献 26)の研究との 連続性を持たせるために選定したものである，なお，砶 材は事前に水に浸けている. 各供試体の体積は, 別府ら の研究 ${ }^{24}$ を参考に，大粒径となる供試体 I とそれ以外の 供試体 II，III の比率を同じになるように作成し，供試 体 Iが $1 \ell$ ，供試体 II， III $1.5 \ell$ とした.

なお，䃏塊の初期位置はスクリーンから $2.5 \mathrm{~m}$ 上流に 置いたうえで，さらに $1.0 \mathrm{~m}$ 上流から水を一気に開放・ 流下させて，水と砂とが混じり合った土石流を生成する. 


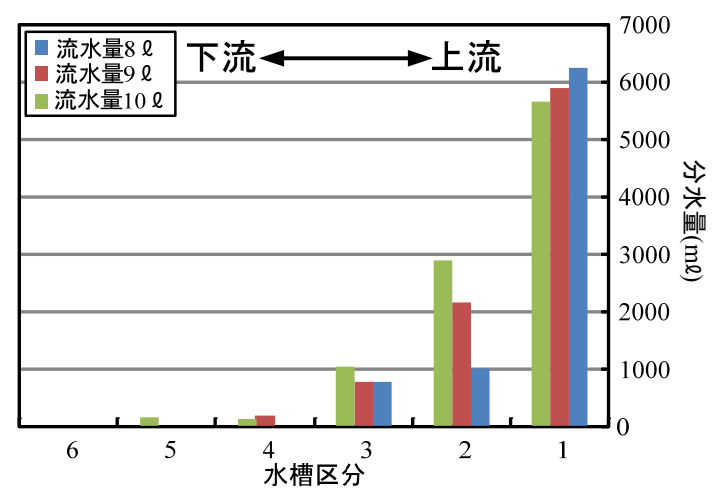

図-16 勾配 $17^{\circ}$ の実験結果（流水のみ）

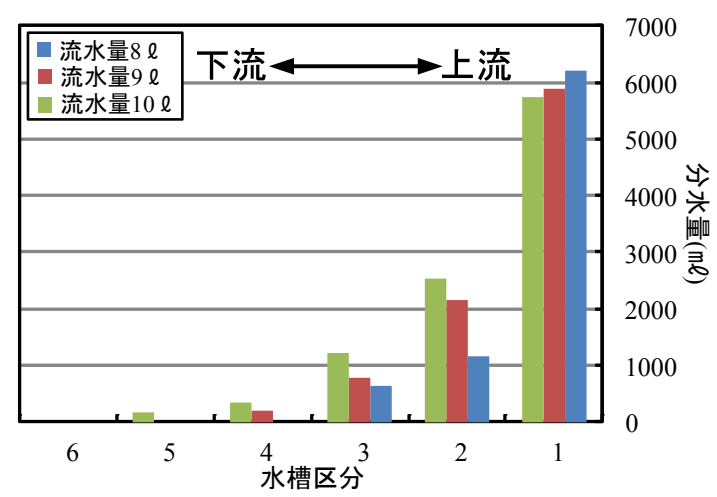

(a) 分水量 水槽区分関係

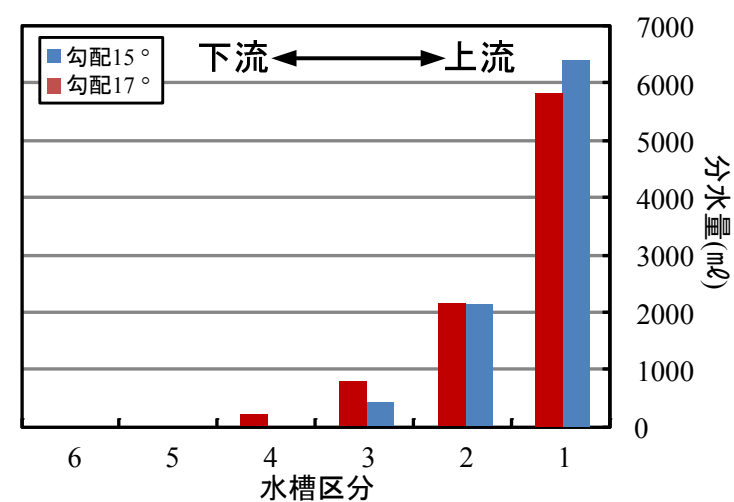

図-17 勾配 $17^{\circ}$ と $15^{\circ}$ の実験結果（流水量 $9 \ell ）$

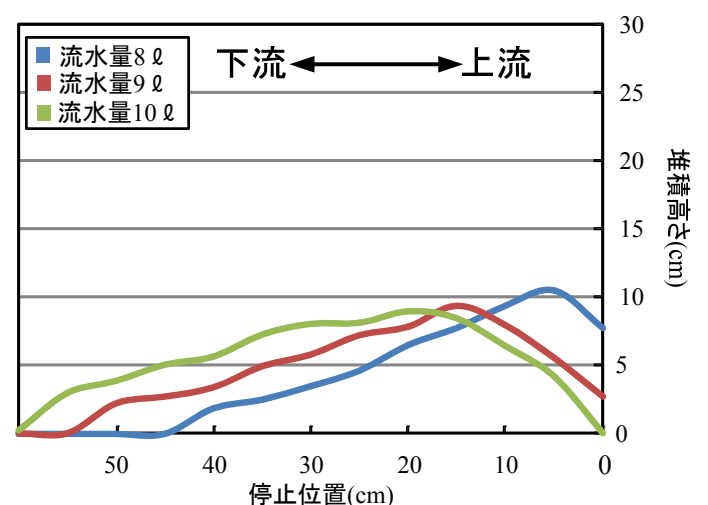

(b) 堆積高さ〜停止位置関係

図-18 勾配 $17^{\circ}$ の実験結果（㗂混じり）

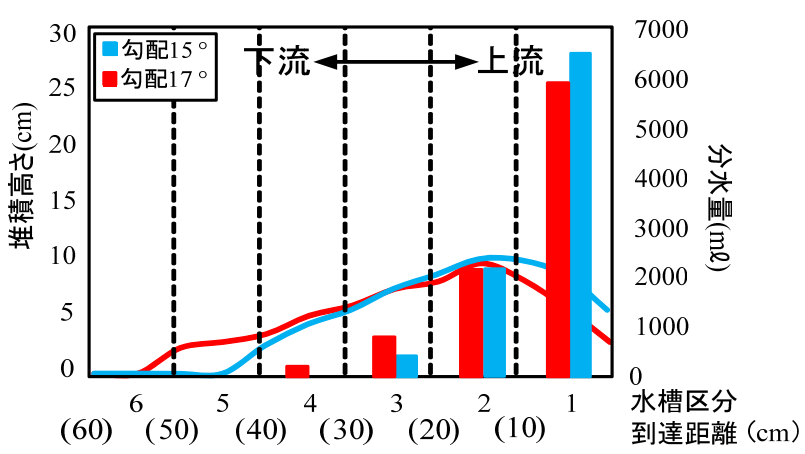

図-19 勾配 $17^{\circ}$ と $15^{\circ}$ の実験結果（硘混じり+流水量 $9 \ell ）$

\section{（2）実験条件}

表-2に，実験ケースを示す．勾配を $\theta=15,17 \circ 02$ 種類 とし，スクリーンまで到達できる最低水量を基準として 8，9，10 凤の3ケースの流量を与える. 比較のため水のみ を流下させ，スクリーンを抜ける水量を計測する実験も 行った. なお，堰堤のスクリーンを塞ぐと磒材は堰堤上 に停止せず流下してしまうことも確認した.

\section{(3) 実験結果}

\section{a) 流水の実験}

図-16は，勾配17 。で流水量8，9，10 との流水のみを流 した場合の各水槽に流下した水量の分布を示している. まず，流水量の影響により水槽区分に分けられる傾向が 異なることがわかる．流水量が増すにつれて水の到達す る位置が遠く下流まで到達している，よって，水槽1で
は，流量が最小である8 ににおけるケースが最も多く， 逆に，水槽 $2 \sim 5$ 以降では，流水量が多く増すにつれて 分水量が増える傾向にある。つまり，流量が増すと流速 が大きくなりスクリーン上の流水の流下距離が長くなる。

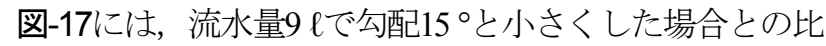
較を示す。参考までに映像から計測された流速は，勾配

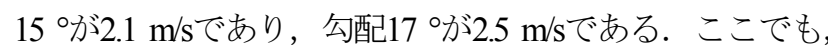
流速が増すと流下距離が伸びている.

b) 礫混じりの実験

図-18に，磒混じり土石流の勾配17 。おおる分水量と 堆積形状を示す。図-18(a)は，各水槽の分水量を示して いる. 流水量が増えるにつれて下流域まで水が到達して いる.ただし，図-16と比較すると砶が混じっているの で，上流側の水槽に多くの水が落下している. 図-18(b) は，写真から堆積した礫塊の形状を描いたものであるが， 流水量が多くなると, 到達位置が下流部まで到達して堆 積塊の長さが伸びている，つまり必要堰堤長が伸びるこ とになる．図-19は，流水量 9 とで，勾配 $15 \circ$ と 17 ○の比 較を示している．勾配が 15 ○少さくなると礫材の停止 位置が $10 \mathrm{~cm}$ ぼ短くなる．また各水槽の水は，15 ○の方 が上流側で落下した分水量が大きくなっている.

\section{（4）堰堤部における堆積過程}

写真-6に，公配17 ○で流水量9 lのスクリーン堰堤への 堆積過程を時系列に示す。まず， $t=t_{0}$ で堰堤部に流下す 


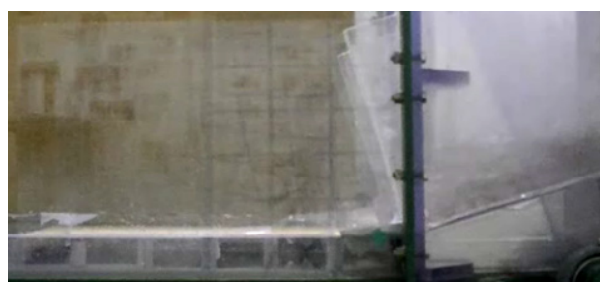

(a) $t=t_{0}$

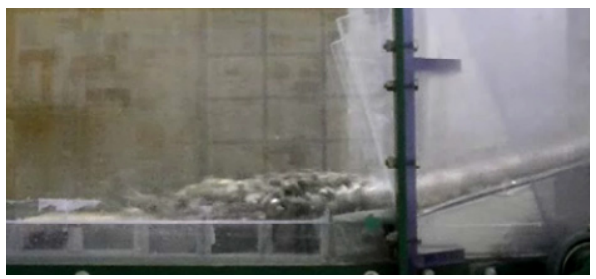

(b) $t=t_{0}+0.3 \mathrm{~s}$

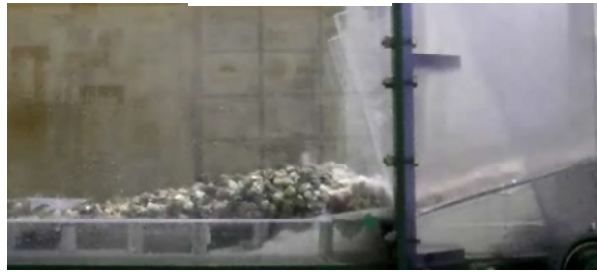

(c) $t=t_{0}+0.6 \mathrm{~s}$

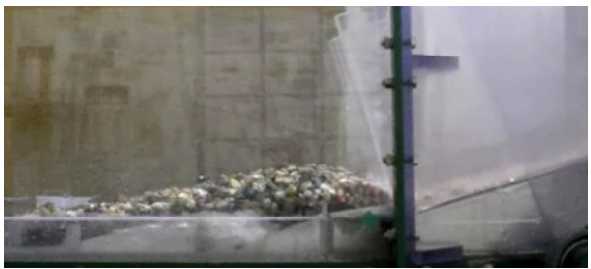

(d) $t=t_{0}+0.9 \mathrm{~s}$

写真-6 勾配 $17^{\circ}$ の堆積過程

る土石流が到達し， $t=t_{0}+0.3 \mathrm{~s}$ には，大半の礫が堰堤部に 停止している. $t=t_{0}+0.6 \mathrm{~s}$ には，後続の砶と水が堰堤部に 乗りかかり，上流側の勾配が急になっている. $t=t_{0}+0.9 \mathrm{~s}$ では，完全に停止した碩塊中に水が流れ続けており，分 水効果により礫が停止している. すなわち，スクリーン に土石流が到達することで河床面に対するせん断抵抗力 が増加することで咸速・停止している．また，堆積過程 から考察すると，堆積した礫の間隙を水が流れることに より，下流側の堆積勾配は，安息角よりも小さくなって いるものと考えられる。つまり，啋間に働く間隙水圧が 有効応力を小さくするために，碩材の内部で働くせん断 抵抗力が低下し，碩塊の下流勾配を緩やかにしている。

\section{4. 底面水抜きスクリーンのシミュレーション}

\section{(1) 計算条件}

\section{a) 解析モデル}

図-20に，解析開始時の碟要素および擬水滴要素の配 置と底面水抜きスクリーンモデルを示す。側面，底面お

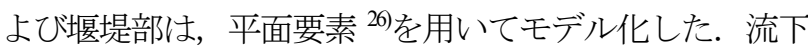
区間における底面は，実験における三角形栈粗度を表現

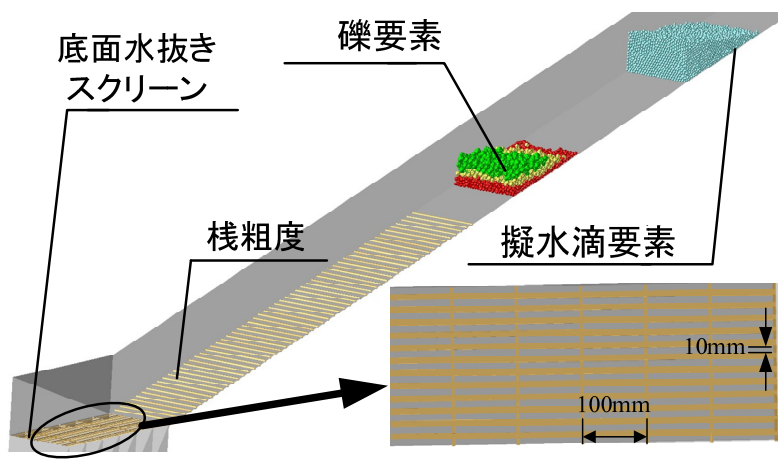

図-20 解析モデル

表-3 解析基本值

\begin{tabular}{|c|c|c|}
\hline \multicolumn{2}{|r|}{ 項 目 } & 值 \\
\hline \multirow{2}{*}{ 礫要素 } & 比 重 $\rho_{g}$ & 1.2 \\
\hline & 要素数 & $1890(11340)$ \\
\hline \multirow{2}{*}{$\begin{array}{c}\text { 擬水滴 } \\
\text { 要素 }\end{array}$} & 比 重 $\rho_{w}$ & 1.0 \\
\hline & 要素数（直径 $r_{w}=1.0 ）$ & $8000 \sim 10000$ \\
\hline \multirow{2}{*}{ 斜路 } & 円柱形要素 & 62 \\
\hline & 平面要素 & 1 \\
\hline \multirow{2}{*}{ 堰堤部 } & 円柱形要素 & 24 \\
\hline & 平面要素 & 48 \\
\hline \multirow{4}{*}{$\begin{array}{c}\text { 要素間 } \\
\text { ばね } \\
\text { (礫要素) }\end{array}$} & 法線方向 $K_{n}(\mathrm{~N} / \mathrm{m})$ & $1.0 \times 10^{6}$ \\
\hline & 接線方向 $K_{s}(\mathrm{~N} / \mathrm{m})$ & $3.5 \times 10^{5}$ \\
\hline & 要素間摩擦係数 $\tan \phi$ & 0.57745 \\
\hline & 减衰定数 $h$ & 0.2 \\
\hline \multirow{3}{*}{$\begin{array}{c}\text { 水ばね } \\
\text { (擬水滴) }\end{array}$} & 法線方向 $E_{w}\left(\mathrm{~N} / \mathrm{m}^{2}\right)$ & $2.25 \times 10^{9}$ \\
\hline & 擬水滴-礫間 $C_{D_{S-w}}$ & 0.4 \\
\hline & 擬水滴要素間 $\eta_{w}$ & 7.0 \\
\hline 時間条件 & 時間刻み $\Delta t$ & $1.0 \times 10^{-7}$ \\
\hline
\end{tabular}

するため，径が同じ円柱形要素 2)を実験と同間隔で配置 している．また，水槽への流水の分岐についての表現は， 水槽を深くして擬水滴要素が溜まるようにしている．擬 水滴要素は, 堰堤からの距離 3.0 4.0 m の間に落下法 ${ }^{26}$ を用いて初期配置した。 ここで落下法は，下流端に直立 する平面要素を立てて，その上流側に要素をランダムに 自由落下させ，要素が移動せず安定した状態を初期位置 とするものである。土石流に混在する砶要素は，実験の 砅径と粒度分布を一致させた。ただし，砶要素は集合体 要素モデルを用いて，6 個の等球径からなる要素を用い た．なお，要素モデルの凸度は，実験で使用した礫の安 息角を測り，これと一致するように定めた ${ }^{27) . ~}$

擬水滴要素と礫要素は，流下開始時点での速度はす心゙ て零としている.

流路の底面と側面は，固体の平面要素を配置して，擬 水滴要素との相互作用は，図-14(c)に示したモデルで処 理をした。 また，スクリーンを構成している面も同様に 平面要素とするので，図-14(c)のモデルで処理するが, 端部は円柱形要素を配置し，図-14(b)のモデルによって 処理した.

参考までに，確認解析として砶材を球形要素でモデル 


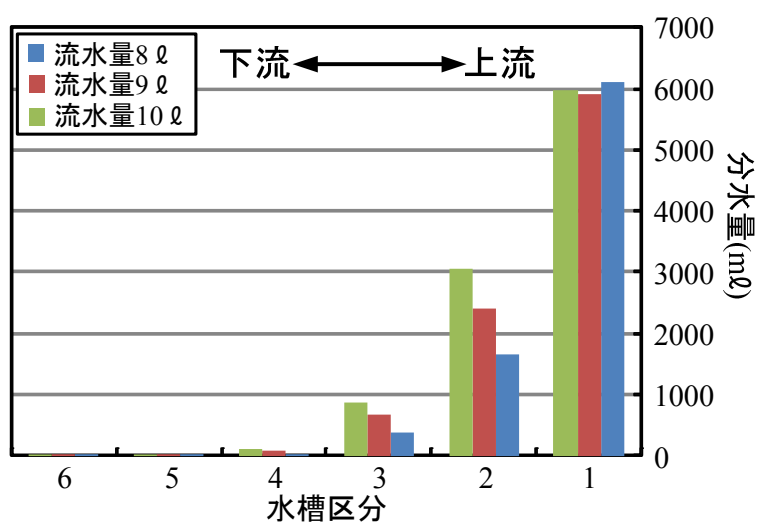

図-21 流水の夕の解析結果 (勾配 $\left.17^{\circ}\right)$

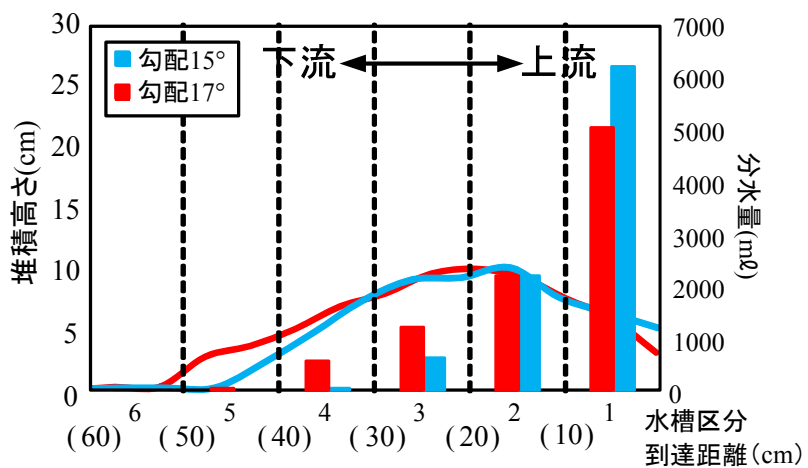

図-23勾配 $17^{\circ}$ と $15^{\circ}$ の解析結果（礫混じり+流水量 $\left.9 \ell\right)$

化すると要素表面に凹凸がないためにスクリーン上で停 止せずに流下してしまう。

\section{b) 解析パラメータ}

表-3に，文献22)，26の土石流解析を参考に決定され た解析基本值を示す，要素間摩擦係数は，文献32)の傾 斜法により決定した。 また，剛体要素の減衰定数は, 0.2 用いた

ところで，擬水滴要素の粒径は，最小砂径と同じもの とした．これは，事前解析によりスクリーン間隔とスム 一ズに抜ける最大粒径サイズとなることを確認し，計算 負担を考慮して決定した.

人工減衰は，擬水滴要素間においては，要素が深さ 10 $\mathrm{m}$ の静水安定解析においても発散せずに安定するものと した. また，磎と水の抗力係数を文献33)を参考にし， 別途行った $1.0 \mathrm{~m}$ 程度の透水試験をモデル化した解析を 行い，実験で通過した水の時刻歴を合せることで決定し た.

なお，日本工業規格の土の透水試験方法 ${ }^{34} に$ にると， 磎における透水係数は約 $100 \mathrm{~cm} / \mathrm{s}$ であるが，これと同程 度の値となっている.

\section{(2) 流水のみの解析}

図-21 は，勾配 17 ○で流水のみの解析結果を示寸，実 験で得られた各水槽への分水量と比較すると $5 \%$ \%ど誤

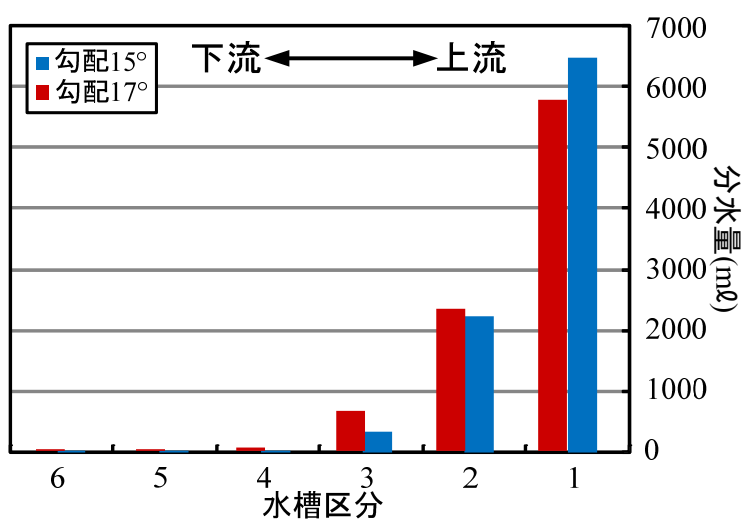

図-22 勾配 $17^{\circ}$ と $15^{\circ}$ の解析結果 (流水量 $9 \ell$ )

差はあるが，ほぼ一致する．また，流水量 $8 ， 9 ， 10$ と 多くすると水が遠方に到達している傾向も表現できてい る. なお，実験と解析の初期位置から堰堤に到達寸るま での時間が一致することも確認している．図-22 には， 流水量 $9 \ell$ と同条件として, 勾配の影響を比較している が実験と同様の結果となっている.

\section{(3) 礫混じりの解析}

図-23は，勾配17 ○と 15 ににおける分水量と堆積形状を 示寸. 各水槽区分における分水量にやや違いがあり，礫 塊の堆積高さにも違いがある。これは，㗂間における流 水の影響や流下中における碩の流れの影響が大きい. し かし，水路勾配の影響により分水量が変化することや礫 塊の堆積位置の影響が勾配の高さで下流側に押し出され ることについては，実験と同傾向を再現できている．つ まり，礫と水に働く水圧と間隙を通り抜ける水の効果を 概ね再現できている.

\section{（4）堆積過程の解析的検討}

\section{a) 接触力分布}

ここからは，勾配 $17^{\circ}$ ，流水量 9 ににおける解析を基に 内部のメカニズムを検討する. 図-24に, 要素間の接触 力分布図を示寸. 図中の赤色の円柱で表示されているの は，碩一碩要素間の接触力であり，径が太いほど大きな 力を示している. また, 砂と擬水滴要素の接触力は水色 で表示しており，擬水滴-擬水滴要素間は表示していな い. 図-24(a)の $t=t_{0}$ は土石流の先頭部が堰堤直前の時間 である. 図-24(b)の $t=t_{0}+0.3 \mathrm{~s}$ は, 磎の先端で大きな接触 力が底面と碅間に生じており，礫に制動力が働いている。 一方, 後方から追いついた擬水滴要素は碩要素を前方に 押しているが，その力は先端にある磎の制動力より弱い ため, 碩塊が停止し始めている様子がわかる.

次に, 図-24(c)の $t=t_{0}+0.6 \mathrm{~s}$ では先端部の制動力がさら に大きく働き，礫群がその場にとどまろうとしている.

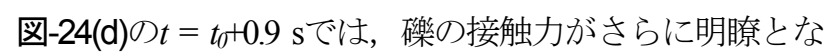
り安定した堆積物が生起したことで硯要素が停止してい 


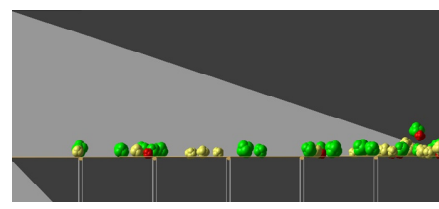

実形状モデル

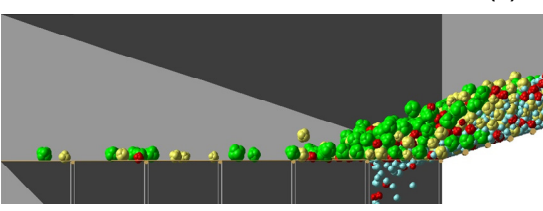

実形状モデル

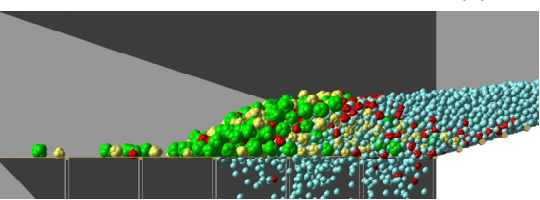

実形状モデル

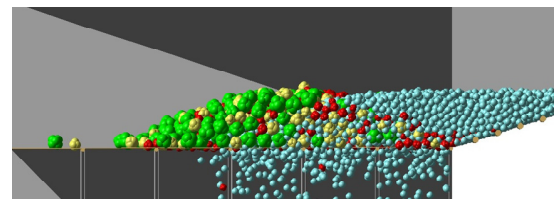

実形状モデル

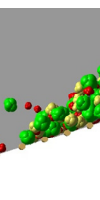

(a)

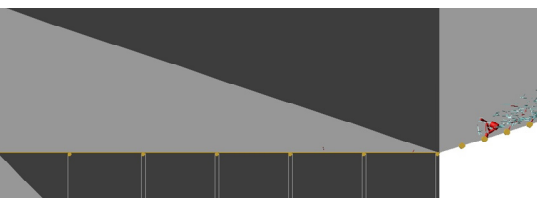

接触力分布図

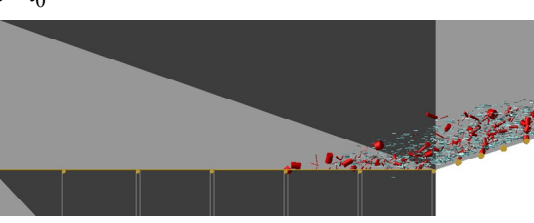

接触力分布図

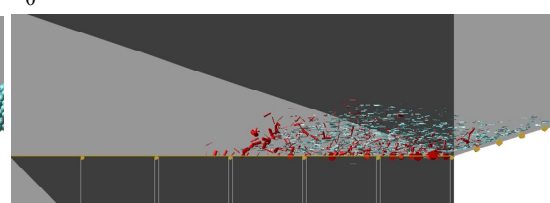

接触力分布図

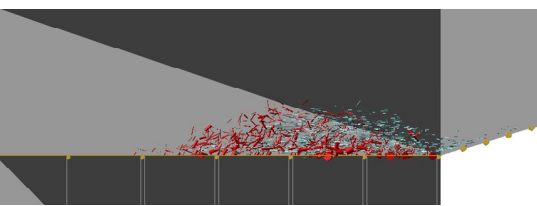

接触力分布図

(d) $t=t_{0}+0.9 \mathrm{~s}$

図-24 堆積過程における接触力分布図

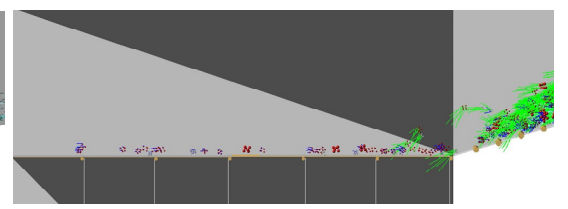

(a) $t=t_{0}$

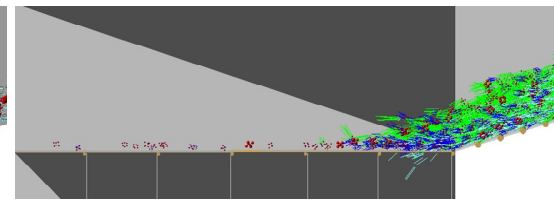

(b) $t=t_{0}+0.3 \mathrm{~s}$

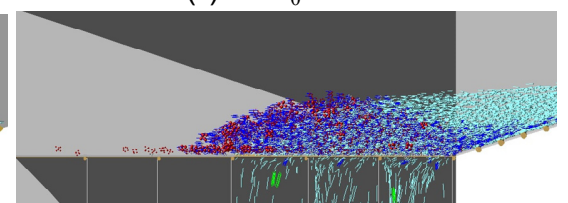

(c) $t=t_{0}+0.6 \mathrm{~s}$

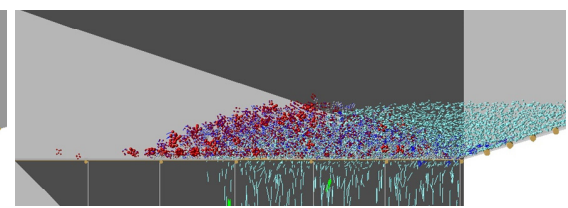

(d) $t=t_{0}+0.9 \mathrm{~s}$

図-25 速度ベクトル表示

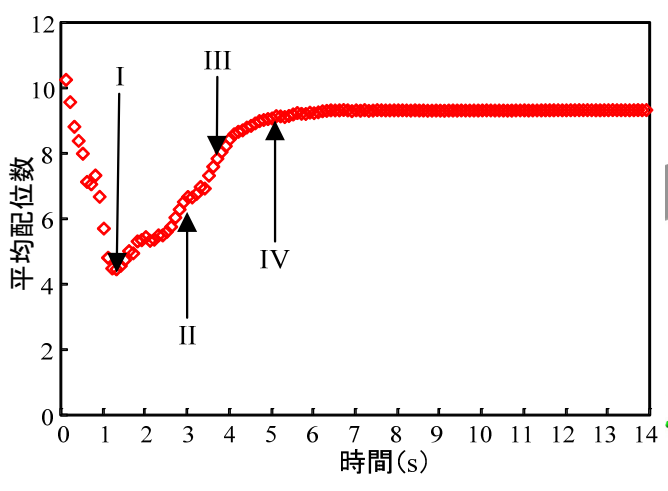

(a) 平均配位数 時間関係 (勾配 $17^{\circ}$ )

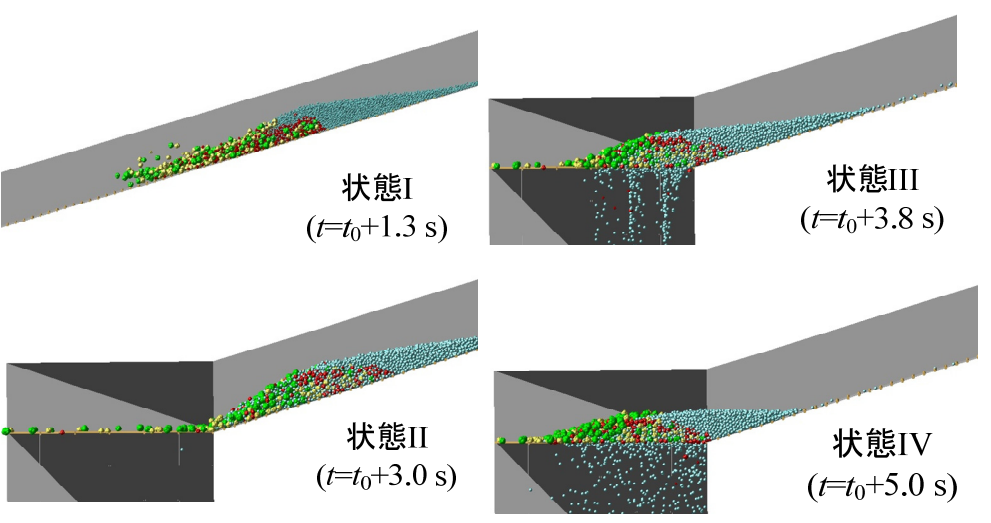

(b) 各領域の状態

図-26 平均配位数と堆積過程

る. 一方，擬水滴群は水槽一流れ落ちるので碩群を前方 へ押す力が失われている.つまり，完全に砶が停止した 後も擬水滴要素は碩間を流れており，擬水滴要素と砶要 素の接触力は小さいながらも継続している.

\section{b) 水の速度ベクトル評価}

図-25は，要素の速度ベクトルを擬水滴要素について は水色の線で，砶については青色で示したものである. ここで， $t_{0}$ とは堰堤に土石流の先端が到達したときであ り, 土石流の先端の速度が最も大きいときでもある. $t=$ $t_{0}+0.3 \mathrm{~s}$ では, 礫が先頭部に集中し, 流速の速い流水が礫 と混じりながら流れている. $t=t_{0}+0.6 \mathrm{~s}$ では, 礫が急激に 減速し, 擬水滴要素が碩間を抜けながら流れている. $t$ $=t_{0}+0.9 \mathrm{~s}$ では, 礫塊が完全に停止状態に入り，後続流が 流れ続けている．碩塊が停止するとその硯間を水が抜け る隙間に抗力が生じるため, 水の流速も減速する. やが て礫は停止するが，擬水滴要素の抗力は碟を動かすほど 大きくないため，間隙を通り抜け続けていることがわか る.

\section{c) 平均配位数の推移}

図-26(a)には，平均配位数〜時間関係を示す. 配位数 とは，個別要素法で時々刻々にカウントされる接触点数 である，構造解析的な視点において，骨格構造の不静定 次数に相当しており, 配位数が増えると, より安定した 骨格構造になる. 状態 $\mathrm{I}\left(t=\widetilde{t}_{0}+1.3 \mathrm{~s}\right)$ は, 図-26(b)に示す 
碩塊が初期位置から流れ始めた状態である．初期位置で は，礫のみであり固体化しているため，最も大きい平均 配位数が10.5である.これが流れ始めて流動化が進むと， この平均配位数は4.5にまで低下している.

次に, 状態 II $\left(t=\tilde{t}_{0}+3.0 \mathrm{~s}\right)$ は, 図-26(b)に示してい る土石流の先頭部が堰堤に到達したときであり，配位数 が6.2と増加途中である. 状態III $\left(t=\tilde{t}_{0}+3.1 \mathrm{~s} \sim \tilde{t}_{0}+3.8 \mathrm{~s}\right)$ では，砶塊が急激に減速している時であるが，平均配位 数が8.4を示し，増加傾向にある.つまり完全に停止し ているわけではない. 状態IV $\left(t=\tilde{t}_{0}+5.0 \mathrm{~s}\right)$ は礫塊が 停止状態であり，平均配位数は9.3に達しており停止に 伴って骨格構造が再度安定化したことがわかる.

このように，土石流の碟群が粒状体としても固体化 $\rightarrow$ 液体化 $\rightarrow$ 固体化と変化する過程に対応して, 剛体要素間 の配位数が大 一小 $\rightarrow$ 大変化する様子がわかる.

\section{5. 結 言}

本研究は，個別要素法を応用した擬水滴要素を提案し， 底面水抜きスクリーンを対象に碟と水の分離によって生 じる土石流の停止機構の再現解析を試みたものである.

1) 実験によると底面水抜きスクリーンのスリットによ って，土石流内部の礫間に働く間隙水圧により有効応力 を小さくすることで，礫塊が形成し減速・停止している. 2) 土石流が堰堤部に到達すると碟と水に分離されるた め水の押し出す力が失われることで，硯と底面に働く制 動力が相対的に大きくなる.

3）流水のみの解析において, 提案する擬水滴要素によ って，実験と同様に底面水抜きスクリーンのスリットで 抜ける水量と上流から到達した擬水滴群の流速が再現で きる.

4) 礫混じりの解析においても, 流れの過程や碟と水の 混合状態と分離挙動は，実験のものと概ね一致している. 5) 本解析では擬水滴要素と砶要素の接触力図を用いて 礫と磎間を流れる水との分析が可能である.

6) 提案手法は，㛜密解な水の振舞いを表現するには, 多くの課題が残されており, 改善および検討を行う必要 がある。

\section{参考文献}

1) 一般社団法人 砂防・地すべり技術センター：土砂災害の実 態 平成 24年度版, pp.1-31, 2013.7.

2) 荻原幸男監修: 日本の自然災害 1995～2009 年 一世界の大 自然災害も収録一, 日本専門図書出版, pp.320, 2009.7.

3) 砂防・地すべり技術センター鋼製砂防構造物委員会 : 平成 21 年版 鋼製砂防構造物設計便覧, 2010.9 .

4) 水山高久, 鈴木宏, 及川義朗, 森田昭宏 : 透過型砂防ダム に関する実験的研究, 新砂防, Vol.41, No.2(157), pp.21-25,
1988.7.

5) 田畑茂清，守山浩史 : 鋼製透過型えん堤工法・設計法の変 遷と課題, 砂防学会誌, Vol.64, No.6, pp.47-51, 2010.3.

6) H. Suwa, K. Okano, T. Takahashi : Behavior of debris flows monitored on test slopes of Kamikamihorizawa Creek, Mount Yakedake, Japan, International Journal of Erosion Control Engineering, Vol.2, No.2, pp.33-45, 2009.7.

7) 清野雅雄, 宮越英紀, 上原信司, 水山高久 : 底面水抜きス クリーンの現地試験, 新砂防, Vol.39, No.3(146), pp.16-20, 1986.9.

8) 今井一之, 宮本登, 水山高久: 底面水抜きスクリーンの現 地試験（続報），新砂防，Vol.42，No.2(163)，pp.23-28，1989.9.

9）橋本規明 : 新河川工法, 森川出版 (株) , pp.224-231, 1956.7. 10) 矢澤昭夫, 水山高久, 森田昭宏 : 土石流を制御する構造物 に関する実験，土木技術資料 Vol.28，No.8，pp.9-14，1986.8.

11)権田豊, 長谷川泰亮, 山本仁志, 松崎健 : 底面水抜きスク リーン上での土石流の停止機構に関する検討，平成 12 年度 砂防学会研究発表会講演集, pp.38-39，2000.5.

12)権田豊, 深澤宣代, 松崎健, 山本仁志, 長谷川泰亮 : 底面 水抜きスクリーン上での土石流の停止機構に関する検討(2), 平成 13 年度砂防学会研究発表会講演集, pp.86-87, 2001.5.

13)権田豊, 富田耕司, 松崎健, 山本仁志 : 底面水抜きスクリ ーン上での土石流の停止機構に関する検討(3), 平成 14 年度 砂防学会研究発表会講演集, pp.48-49, 2002.5 .

14)権田豊, 上岡秀之, 山本仁志, 川邊洋 : 土砂が堆積した底 面水抜きスクリーン上での土石流の挙動, 平成15年度砂防学 会研究発表会概要集, pp.112-113，2003.5.

15)清水賀之, 落合博貴, 岡田康彦 : 間隙水圧を考慮した粒子 一流体連成モデルを用いた個別要素法による土石流シミュ レーション, 土木学会論文集C, Vol.65, No.3, pp.633-643,

2009.7.

16)清水賀之, 稲川雄宣: 間隙水圧を考慮した粒子一流体連成 モデルを用いた個別要素法による液状化解析, 土木学会論 文集C, Vol.66, No.4, pp.800-813，2010.11.

17) 福田朝生, 福岡捷二, 内田龍彦 : 水流による石礫粒子群の 移動機構とそのモデル，土木学会論文集B1（水工学）,

Vol.68, No.4, I_937-I 942, 2012.2.

18) 加藤宏隆, 大槻政哉, 斎藤佳彦, 清水康行, 木村一郎 : MPS 法を用いた雪崩シミュレーションモデルの実用化に向 けた検討，土木学会論文集B1（水工学），Vol.67，No.4， I_1231-I_1236，2011.2.

19) 浅井光輝, 別府万寿博, 石川信隆, 眞鍋慶生, 齋藤展, 丹 羽一邦 : 数值流体シミュレーションによる流体衝撃力評価 に関する基礎的研究，構造工学論文集 Vol.58A，pp.1021-1028, 2012.3.

20)福間雅俊, 前田健一, 湯浅知英 : 石磎流れ中の分級と跳返 りのメカニズムに関する考察，実務利用を目指すマイクロ ジオメカニックスに関するシンポジウム, pp.1-6, 2008.11. 
21) 前田健一, 舘井恵, 福間雅俊 : 個別要素法を用いた粒子流れ の構造と大粒径の浮き上がりのマイクロメカニクス, 砂防学 会誌, Vol.64, No.4, pp.3-14, 2011.6.

22)渋谷一，原木大輔，香月智 : 3 元個別要素法による透過型 砂防えん堤の流木混じり土石流の捕捉シミュレーション， 応用力学論文集, Vol.12, pp.449-460, 2009.8.

23)渋谷一，堀口俊行，香月智，大隅久，石川信隆 : 円柱形集 合体要素を用いた個別要素法による根付き流木の捕捉シミ ユレーション，土木学会論文集 A2(応用力学)特集号, Vol.67, No.2, pp.I 323-I 334，2011.8.

24)別府万寿博, 井上隆太，石川信隆，長谷川祐治，水山高 久: 修正 MPS による土石流段波モデルのシミュレーション 解析，砂防学会誌，Vol.63，No.6，pp.32-42，2011.3.

25)P.A Cundall : A computer model for simulating progressive large scale movement in blocky rock system, Proc. Symp. ISRM， Nancy France, Vol.2, pp.129-136, 1971.

26)香月智，渋谷一，大隅久，國領ひろし，石川信隆 : 個別要 素法による透過型砂防堰堤の流木混じり土石流捕捉解析,
土木学会論文集 A2(応用力学), Vol.69, No.1, pp.16-29, 2013.2.

27)堀口俊行, 渋谷一, 香月智, 田附正文 : 集合体要素の形状 特性が安息角に及ぼす影響に関する解析的検討, 構造工学 論文集，Vol.57A，pp.136-146，2011.3.

28) 池田駿介 : 水理学，技報堂出版，1999.1.

29) G.R.Liu, M.B.Liu : Smoothed Particle Hydrodynamics : a meshfree Particle method, World Scientific, 2003.

30) 小坪清真 : 土木振動学, 森北出版, pp.204-222, 1973.4.

31) 富永章宏，田本典秀：三角形断面栈型粗度を有する開水路 流れの乱流構造，応用力学論文集，Vol.5，pp.727-734，2002.8. 32)田中久一郎：摩擦のおはなし, 日本規格協会, pp.133134, 1985.3.

33)池田駿介 : 水理学，技報堂出版，1991.1

34）（公社）地盤工学会 : 土質試験 基本と手引き 第二回改 訂版，2010.3.

(2014.6. 20 受付)

DEM SIMULATION ON DEHYDRANT BEHAVIOR OF DEBRIS FLOW CAPTURED BY BOTTOM DRAINAGE SCREEN DAM

\section{Toshiyuki HORIGUCHI, and Satoshi KATSUKI}

This paper presents a new Distinct Element Method to simulate coupled behavior of water and gravels. A spherical shape water element is proposed. The element has an isotropic pressure controlled by shrinkage volume of its body, and transfers the pressure to adjacent elements in proportion to the contact section area. Combining the water elements and conventional element, i.e., spherical or aggregate rigid body experiments, debris flow behavior obtained by experiment are simulated. The experiments are performed on the dehydrate behavior of debris flow captured by a bottom drainage screen dam. Draining out water from debris flow, the gravels lose its fluidity on the screen. The proposed method simulates such behaviors very well, and the coupled mechanism is analyzed in viewpoints of reaction force between rigid and water elements, and coordination number transition in the rigid elements. 